\title{
Evaluation of Malaysian Retail Service Quality
}

\author{
Zalina Ibrahim ${ }^{1}$, Linda Dana ${ }^{1}$, Ahmad Faisal Mahdi ${ }^{1}$, Mohamad Zaid Mohd Zin ${ }^{2}$, Mohd Anuar Ramli ${ }^{3}$ \& Mohd \\ Roslan Mohd Nor ${ }^{3}$ \\ ${ }^{1}$ Faculty of Business Management, Universiti Teknologi MARA, Kota Samarahan, Malaysia \\ ${ }^{2}$ Centre for Islamic Thought and Understanding, University Technology Mara, Samarahan, Malaysia \\ ${ }^{3}$ Department of Islamic History and Civilization, Academy of Islamic Studies, University of Malaya, Kuala \\ Lumpur, Malaysia \\ Correspondence: Zalina Ibrahim, Faculty of Business Management, Universiti Teknologi MARA, Kota \\ Samarahan, Malaysia. E-mail: zaiduitm@gmail.com
}

Received: January 14, 2013 Accepted: February 25, 2013 Online Published: March 28, 2013

doi:10.5539/ass.v9n4p14 URL: http://dx.doi.org/10.5539/ass.v9n4p14

\begin{abstract}
In retailing different requirement of service quality in product or services environment required. Some of the retail stores have lack on service quality whereas the salesperson is not well trained, unknowledgeable and rude. This study aims to evaluate the retail service quality from a supermarket in Kuching, Malaysia and sets out to determine what influence customers to shop. This research looks at the five dimensions of retail service quality: the physical aspect, reliability, personal interaction, problem solving and policy. A survey of 200 respondents was conducted and reliability test is measured to represent the dimensions whereas regression test and Pearson correlation is used to answer the research questions and testing the hypotheses. The overall finding confirms the importance of quality service, the need to upgrade services to remain competitive, and consideration by government on modernization of retail outlets using the credit card will bring burden to the consumers as against the benefits. In addition, implications of this study as well as directions for future research are discussed.
\end{abstract}

Keywords: retail service, physical aspect, reliability, personal interaction, problem solving, policy

\section{Introduction}

Service quality is being increasingly perceived as a tool to increase value for the consumer; as a means of positioning in a competitive environment to ensure consumer satisfaction and retention. "Service quality has been seen as critical for service firms to position themselves strongly in a competitive environment (Parasuraman, et al., 1985, Shemwell et al., 1998; Mehta et al., 2000) and also as indicators of business performance" (Hurley \& Estelami, 1998).

When consumer is satisfied with the service, they will tend to be loyal (Mehta, Lalwani \& Han, 2000). Service quality in retailing is different from any other product/service environment (Finn \& Lamb, 1991; Gagliano \& Hathcote, 1994). Some of the retail stores lacking on service quality whereas the salesperson is not well trained, unknowledgeable and rude.

Moreover, any complaints or problem faced by customers is not taken seriously by the management itself. For the retailers, as long as they get profit they will feel that their business is successful. As the retailers too much concentrates on the productivity and the profitability, the retailers was over looked on the retail service quality.

According to Carlzon (1987) that is why the supermarket managers are suggested to be more concerned with or not customer develop positive feelings towards the contact employees as well as supermarket itself because an unsatisfactory service encounter or "moment of truth" can lead to a loss of sale and potentially to diminished customer loyalty. Moreover, the behavior of consumers in Malaysia has also changed in their lifestyle, which impacts on the way they purchase their food.

Several factors including an increase in personal disposable income, greater urbanization, a greater awareness of food safety and food quality issues, and changes in diet are influencing the preferred place of purchase (Wong 2007). With more purchasing power, consumers have more choice as to where and when they purchase their food. Furthermore, most of the customers do not see the inner operations of a service establishment.

Yet, this unseen area can be a customer's major concern if not the primary factor when choosing a particular 
service establishment (Yamanaka et al, 2003). Therefore, this study aims to evaluate the retail service quality from a supermarket, in Kuching. For this research purposes, the supermarket will be acknowledged as Supermarket X. Malaysia and sets out to determine what influence customers to shop in order to maintain their position and to be at the same level as other supermarkets.

\section{Literature Reviews}

Retailing can be in categorized in three groups such as convenience goods which include groceries and daily provisions, shopping goods which refer to quite more expensive items bought at less regular intervals and specialty goods which are unique items that request to customers of the higher income level (Guy, 1980).

There are two types of retailers such as small-scale retailers and large-scale retailers. Small-scale retailers include the single-propriety stores and non-store operators such as hawkers, peddlers and market stalls. Moreover, large-scale retailers include superstore, discount store, department store, supermarket, hypermarket and shopping center (Ahmad et al., 1996; Nik Yacob et al., 1992; Cox, 1988). Retail stores belong to service industry, which offer a mix of goods and service, thus retail product management not only have the common characters of goods quality but also have the special characters of services quality.

\subsection{Retail in Malaysia}

The retail environment in Malaysia has undergone a continuous and marked change over the decades. New facilities ranging from supermarkets and superstores to retail warehouses and convenience stores have been added to the retail landscape, much at the expense of traditional shop houses. Retail in Malaysia is wide-ranging; from department stores, supermarkets and mini markets, specialty shops, convenience stores, provision stores, pharmacies, medical halls, direct sale, wet market stalls to pavement shops and petrol kiosks (Seventh Malaysia Plan, 1996).

In Malaysia, the structure of food retailing has changed dramatically over the last few years, which before this the only retail formats were the traditional markets, grocery stores or mini-markets. In Malaysia, supermarkets began to emerge in the early 1990's (Wong, 2007). Modern retail outlets such as supermarkets and hypermarkets are dominating the local retail food trade (Shamsudin \& Selamat 2005). It is because of the various external forces such as customer behavior, increased number of competitors, legislative framework, technological advancement, and changes in societal status and values (Lusch, 1982).

\subsection{Customer Knowledge and Behavior on Buying Product and Services}

Customer will have experience and knowledge before consuming the goods or services to fulfill their needs (Caru' \& Cova, 2003). All the experience will be taken as a guideline other than somebody's opinion such as from our family, close friends other than the suggestion from the promoter. Consumer also can get as many as possible the information on the product that they want through electronic and printed media. These facilities make consumers become more knowledgeable and demanding. Nowadays, customers demand and expectation always change from time to time for better quality and services.

\subsection{Retail Service Quality}

Retail service quality is also highly associated with future consumption behaviour in terms of the customers' intention to visit, purchase and recommend the store to family and friends. In retail setting especially retail stores where there is a mix of products and services, retailers are likely to have impact on service quality more than on product quality (Dabholkar et al., 1996).

This will relate to the intense competition among the supermarket and each of the supermarkets will need to offer something that has value for money to their customers. The offering will be their competitive advantage and that is why the retail service quality becomes important. It is significant for retailers to evaluate and make some changes on their services because these business strategies will make the difference and gain a lot of profit because total sales is not the big issues but profit will be the main aim for each of the supermarket.

\subsection{Theoretical Framework}

Dabholkar et al. (1996) have developed a validated Retail Service Quality Scale to measure retail service quality specifically. This scale is different because it is suitable for studying retail businesses that offer a mix of services and goods such as department or specialty stores (Dabholkar et al., 1996). However it has not been applied in other cultures which this study at-tempts to apply the Retail Service Quality Scale in the Supermarket X as a case study. This study is very useful because it measure the effectiveness of the retail service quality on Supermarket $\mathrm{X}$ in competing with their competitors. Therefore; all of the dimension will be explain as follows: 


\subsubsection{Physical Aspect}

In physical aspect it emphasizes on modern looking equipment and fixtures, cleanliness and the store layout. This statement was supported by Geuens et al (2003) which refer to the store that provides facilities such as car parking, trolleys and baskets, proximity to other shops, extended trading hours, a low level of in-store crowding, good presentation of products, signage, and the desired width and depth of the product range.

Furthermore, it is important to emphasize on physical aspect according to Yalch and Spangenberg (1990), the right use of color, lighting, sound and furnishing may stimulate perceptual and emotional responses within consumers, which eventually affects their behavior. Espinoza et al. (2004) further state that a good store atmosphere and pleasant surroundings may increase the consumers' willingness to buy.

The consumers will only choose to shop at the store if they perceive the store has the same image desired by them. However, store image or attributes cannot be determined unless the store dimension is important to the consumers and there is a noticeable difference across the chain (Seiders \& Tigert, 2000).

\subsubsection{Reliability}

Reliability is focusing on the availability of the merchandise, insists on error free sales transactions and records also on the time of the service. Thus, supermarket is perceived to be capable of offering a wide variety of food and non-food items for consumers. The reliability dimension is one of the important criteria for Supermarket X because based on Mui et al. 2003, when asked why they shop at shopping malls, the majority of respondents in Malaysia cited the variety of shops and products as the main criteria to shop at modern retail outlets.

Morganosky (1997), Seiders and Tigert (2000) and Carpenter (2008), found that consumer preferences are affected by the perception of variety within a selection and the store itself. Thus, more and more retailers are opening new stores with a large footprint in order to be able to offer a wide variety in their product range. This is because retailers are afraid that shoppers will be less likely to shop in the store if they feel that the store has less of a product range compared to others. Besides merchandising assortment, some researchers also found that the arrangement of the products, the repetition of items, and the availability of consumers' favorite or alternative items will also affect consumers' perception of product assortments (Kahn \& Lehmann, 1991; Broniarcyzk, 1998; Hoch et al, 1999).

\subsubsection{Personal Interaction}

This dimension will be concentrate on the knowledge, treatment and also the prompt service by the employees of the store. Hence, to verify the importance of personal interaction towards Supermarket X; Abu (2004) agrees with the importance of personal interaction between vendors and customers which eventually develops customer loyalty. Customers are more loyal to a store which offers warm and friendly service.

Factors such as the ability to truthfully answer customers' questions, giving regular customers individual attention and vendors' knowledge of their product attracts customers to shop from a particular retail outlet (Dabholkar et al. 1996; Darian et al. 2001). Furthermore, they are strongly in favour of the halal label and the slaughtering method for the reason of convenience shopping (Bonne \& Verbeke 2006). What customers perceive as good service can be having knowledgeable, helpful and courteous salespeople. Small things like smiling, greeting and establishing eye contact may also give the customers a positive feeling about the store (Winsted, 1997).

\subsubsection{Problem Solving}

The purpose of problem solving dimension is to highlight on the willingness of the employees to handle returns and exchanges, solves the customer problems and also complaints directly and immediately. Besides the store personnel's service, Lindquist (1974-1975) has also identified return or exchange policy, delivery service and credit policies as the attributes of service.

To confirm the above statement, according to Trappey and Lai (1997), younger consumers who are more occupied with work and family prefer to shop in modern retail outlets which better satisfy the needs of a faster-paced lifestyle. Shoppers who purchase from modern retail outlets do not always live near the supermarkets. Convenience for them meant one-stop shopping.

\subsubsection{Policy}

The important elements for Policy are the plenty of convenient parking, convenient operating hours and also the quality of products and foods offers. There are several advantages for Supermarket $\mathrm{X}$ to focus on policy as stated by Abu, 2004, although the prices of certain similar items may be relatively higher than traditional markets, consumers still shop at modern retail outlets due to comfort and good parking facilities . 
Thus, an excellent service with convenience was seen from the shoppers' perspective as selecting their preferred shopping outlet based on hours of operation and travel time (Kaufman 1996). Moreover, according to Sloan et al. (1984) and Steenkamp and Van Trijp (1989), consumers are willing to pay more to purchase the quality food they demand. With more consumers having higher education and being more practical, Farhangmehr et al. (2000) highlighted the importance of quality, followed by price when purchasing food.

\section{Theorethical Framework}

In this research, three main variables were used such as Independent Variables, Moderating Variables and Dependent Variables. First of all, the independent variables in this study are Physical Aspect, Reliability, Personal Interaction, Problem Solving and Policy. Next, in physical aspect the questions will be on the equipment, cleanliness and the layout, reliability will be asked on availability of merchandise, the error-free sales transactions and records also about the time of the services.

Besides that, personal interaction is about the knowledge of the employees in Supermarket X, their attitude in servicing their customer and how fast they provide their services. Moreover, problem solving is about how the employees handle returns, exchange, problems and complaints. Thus, policy will include the availability of parking, convenient of operating hours and also the quality of the merchandise that Supermarket X offer to their customers.

As for moderating variables it would be the demographic profile of the respondents such as gender, marital status, age, occupation, income, race and number of visit to Supermarket X per week. Meanwhile, the dependent variable is the Retail Service Quality itself.

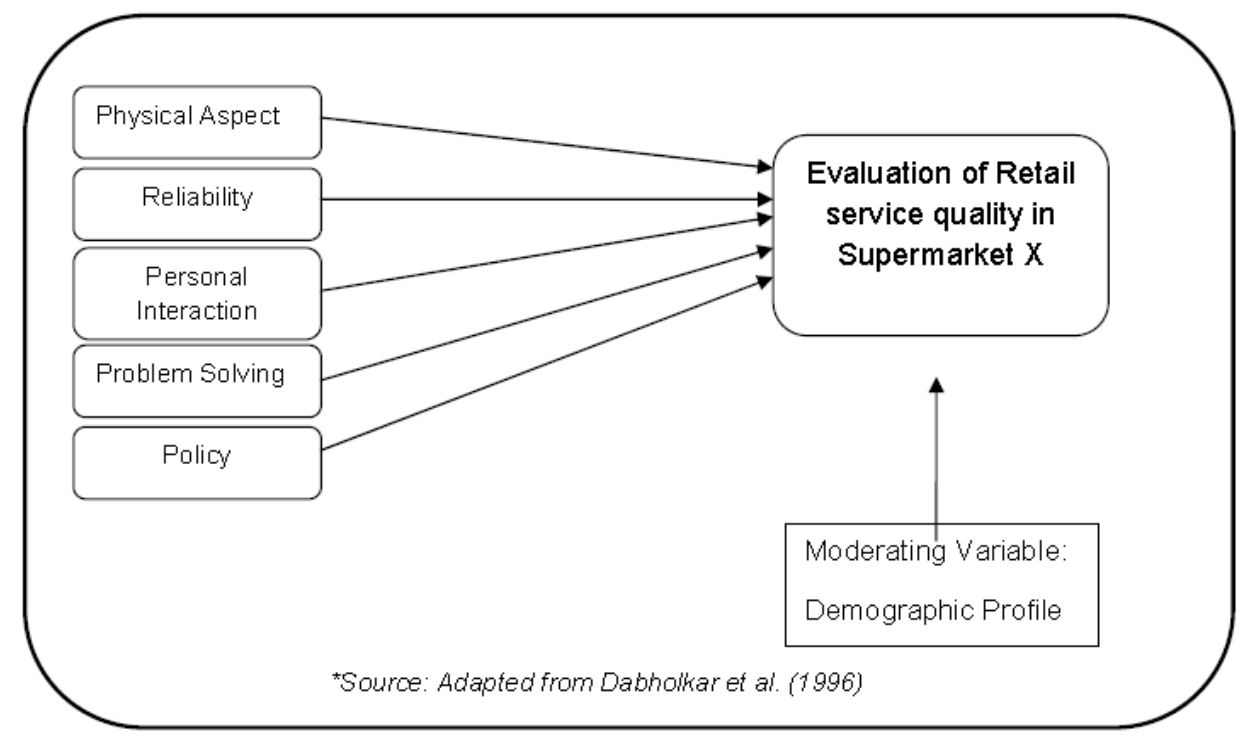

Figure 1. Relationship between five dimensions with retail service quality

The theoretical framework is adapted from Dabholkar et al. (1996). The original theoretical framework by Dabholkar et al. (1996) has been made a slight change to put the moderating variable that is demographic profile. Hence, from the theoretical framework, below are the hypotheses formed:

\section{Hypotheses}

$\mathrm{H} 1$ : There is a significant positive relationship between the five dimensions and Retail service quality

1) There is significant positive relationship between physical aspect and retail service quality

2) There is significant positive relationship between Reliability and retail service quality

3) There is significant positive relationship between Personal Interaction and retail service quality

4) There is significant positive relationship between Problem solving and retail service quality

5) There is significant positive relationship between Policy and retail service quality 


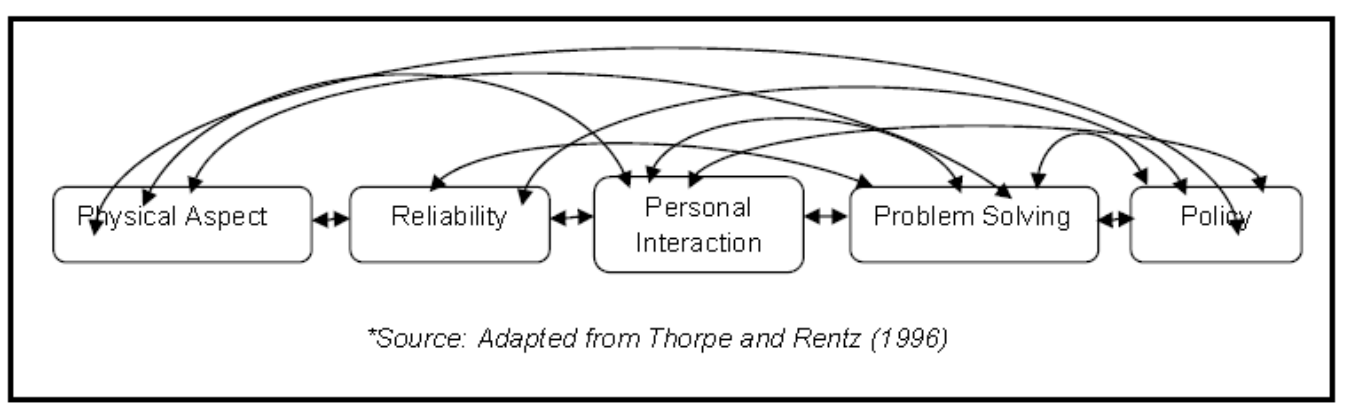

Figure 2. Relationship among five dimension itself

Physical_Aspect<--> Policy

Physical_Aspect $<-->$ Personal_interaction

Personal_interaction<--> Policy

Physical_Aspect $<-->$ Reliability

Reliability<-_>Personal_interaction

Personal_interaction<-->Problem_solving
Problem_solving $<-->$ Policy

$$
\text { Reliability<-->Policy }
$$

Reliability<-->Problem_solving

Physical_Aspect<--> Problem_solving

\begin{tabular}{lccc}
\hline Variable & Dimension & Items (15) & Source \\
\hline Section B & Physical Aspect & 3 & (Dabholkar et al., 1996) \\
Reliability & 3 & (Dabholkar et al., 1996) \\
& Personal Interaction & 3 & (Dabholkar et al., 1996) \\
Problem Solving & 3 & (Dabholkar et al., 1996) \\
Policy & 3 & (Dabholkar et al., 1996)
\end{tabular}

\section{Methodology}

\subsection{Data Collection}

Data collection used in this study was primary data through self administered questionnaire. All of the information was directly from the respondent which the respondent will be given a questionnaire to be filled up. To support the information, secondary data was also conducted.

\subsection{Data Editing and Coding}

Editing is used to identify omissions, ambiguities and errors in the responses. Thus, it is done before data analysis.The omissions will occur when the respondents fail to answer a single question of the questionnaire, ambiguities take place when the respondent answer is unclear for meaning it has more than one answer for one question and the errors in response is happened due to inconsistence from the respondent answer and lack of cooperation.

Coding involves the categorizing and numbering of responses. The codes assign after the data have been collected and before they are entered for analysis which is known as post coded. For example, gender is numerical variable or on the other word known as nominal. Thus, the coding will be 1 for male, 2 is for female. Meanwhile, the ordinal or continuous variable will be represented by age and the coding is 1 for 19 and below, 2 for 20 to 30,3 for 31 to 40,4 for 41 to 50 and 5 is for 51 and above.

\subsection{Data Preparation and Data Analysis}

After collecting all of the questionnaires, all of the data will be key-in into SPSS version 14.0 to process the data in the form of tables and pie charts for easy interpretation as well as for easy understanding of the future readers. Meanwhile, the findings will be evaluate by using SPSS version 14.0.Each of the findings will be verify using several analysis such as frequency distribution, reliability, validity, regression, independent t-test and one way ANOVA.

\section{Findings and Discussion}

There are several test were conducted to analyses this study such as: 


\subsection{Frequency Distribution}

Table 1. Respondents profile based on gender

\begin{tabular}{|c|c|c|}
\hline Variables & Frequency & Percentage (\%) \\
\hline \multicolumn{3}{|l|}{ Gender: } \\
\hline Male & 70 & 35 \\
\hline Female & 130 & 65 \\
\hline \multicolumn{3}{|l|}{ Marital Status: } \\
\hline Single & 136 & 68 \\
\hline Married & 64 & 32 \\
\hline \multicolumn{3}{|l|}{ Race: } \\
\hline Malay & 177 & 58.5 \\
\hline Iban & 37 & 18.5 \\
\hline Bidayuh & 28 & 14.0 \\
\hline Melanau & 5 & 2.5 \\
\hline Chinese & 3 & 1.5 \\
\hline Others & 10 & 5.0 \\
\hline \multicolumn{3}{|l|}{ Age: } \\
\hline 19 and Below & 25 & 12.5 \\
\hline $20-30$ & 107 & 53.5 \\
\hline $31-40$ & 30 & 15.0 \\
\hline $41-50$ & 33 & 16.5 \\
\hline 51 and Above & 5 & 2.5 \\
\hline \multicolumn{3}{|l|}{ Occupation: } \\
\hline Government & 28 & 14.0 \\
\hline Non-government & 17 & 8.5 \\
\hline Self-employed & 37 & 18.5 \\
\hline Unemployed / Student & 118 & 59.0 \\
\hline \multicolumn{3}{|c|}{$\begin{array}{l}\text { Number of visiting to Supermarket } \mathrm{X} \text { (per } \\
\text { week): }\end{array}$} \\
\hline Once & 85 & 42.5 \\
\hline Twice & 100 & 50.0 \\
\hline Three & 7 & 3.5 \\
\hline Four & 3 & 1.5 \\
\hline More than Five & 5 & 2.5 \\
\hline \multicolumn{3}{|l|}{ Income (RM): } \\
\hline Below 1000 & 132 & 66.0 \\
\hline $1001-2000$ & 30 & 15.0 \\
\hline $2001-3000$ & 20 & 10.0 \\
\hline $3001-4000$ & 9 & 4.5 \\
\hline $4001-5000$ & 7 & 3.5 \\
\hline Above 5001 & 2 & 1.0 \\
\hline
\end{tabular}


According to the Table 1, this are the result for 200 respondents .The frequency distribution among gender state that most of the respondents for this study are female which are 130 persons equivalent to 65 percent than male which is only 70 persons at 35 percent. Meanwhile, marital status indicates that most of the respondents in this study are single with the total 136 persons equivalent to 68 percent more than married respondent with the total 64 person at 32 percent. The Malay respondents contribute the most to the research finding which consist of 177 person at 58.5 percent followed by 37 person for Iban respondents at 18.5 percent, then 28 person for Bidayuh respondents at 14 percent, 10 persons for other races at 5 percent, meanwhile 5 person for Melanau respondents at 2.5 percent and a few from Chinese respondents with the total 3 person at 1.5 percent for race. Moreover, the frequency for age reveals that the range of 20 to 30 years contribute most of the research finding which 107 people at 53.5 percent. Followed by, 33 respondents those who are in the age $41-50$ years at 16.5 percent, 30 respondents in the range of 31-40 years at 15 percent, as for respondents in the range of 19 and below the total is 25 persons at 12.5 percent and the lowest is in the range of 51 and above equivalent to 2.5 percent. Table shows the respondents profile based on occupation the respondents is unemployed or student with the total of 118 people at 59 percent. Followed by 37 respondents for self employed at 18.5 percent, government worker is the third highest with the total of 28 people at 14 percent and a few respondents for non-government is only 7 persons at 8.5 percent. Other than that, out of 200 respondents in this study the number of visits to Supermarket $\mathrm{X}$ is dominated by twice per week by the total of 100 people at 50 percent respondents. Once a week was the second highest by 85 people at 42.5 percent and followed by seven respondents for three times per week at 3.5 percent, as more than 5 there were 5 respondents at 2.5 percent. The income per month for the respondent in this study, out of 200 respondents it was dominated by those income in the range of below RM1000 with the total 132 persons at 66 percent, followed by the range between RM1001 to RM2000 equivalent to 30 persons at 15 percent, then 20 person of respondent under RM2001 to RM3000 at 10 percent, 9 persons of the respondent were in the range of RM3001-RM4000 at 4.5 percent. As for 4001 to 5000 the respondent were 7 people at 3.5 percent and a few for RM5001 and above with the total of 2 people at 1.0.

\subsection{Reliability Analysis}

A reliability test is conducted to ensure that the instrument measures are consistent and stable over time (Cavana et al., 2001). In other words, the reliability of the measure is without bias (error free) and, hence, ensures consistent measurement across time and across the various items in the instruments.

Table 2. Review of the whole dimension

\begin{tabular}{llccc}
\hline \multicolumn{1}{c}{ Dimensions } & No. of Items & Cronbach's Alpha & Mean \\
\hline 1. & Physical Aspect & 3 & 0.885 & 5.848 \\
2. & Reliability & 3 & 0.817 & 5.345 \\
3. & Personal Interaction & 3 & 0.890 & 5.080 \\
4. & Problem Solving & 3 & 0.888 & 5.343 \\
5. & Policy & 3 & 0.927 & 6.058 \\
\hline
\end{tabular}

Significance level at $\mathrm{p}<0.05$

The Cronbach's Alpha value that obtained from the reliability test for the entire dimension is more than 0.7. On the reliability test computations, if the alpha is more than 0.7 the reliability is satisfactory and the reliability is said to be very reliable according to (Malhotra, 2003; Nunally, 1978). Thus, this shows that the Cronbach's Alpha for all the items in every dimension is very reliable to be representing all of the dimensions in Section B in the question-naires. Hence, the entire item for physical aspect, reliability, personal interaction, problem solving and policy are reliable to evaluates the retail service quality for Supermarket $\mathrm{X}$ because there were no item to be deleted in the questionnaire.

Moreover, this were supported by the value of means for the entire of the dimensions which is 5.0 and above which means all the respondents were understand and slightly agree with every items representing each of the dimensions and there are no misunderstanding, misconception and misleading questions.

\subsection{Validity Analysis}

The validity test is carried out to ensure that the instrument is tapping the right concept (Cavana et al, 2001). In other words, it is to confirm that the questions in the questionnaire are measuring the intended concept and not 
something else. In most studies, factor analysis was used to reduce a large number of related variables to a more manageable number. The measurement that has been used in this study is based on:

Table 3. Guttmann's rules of thumb

\begin{tabular}{cc}
\hline Coefficient Size & Strength of the relationship between each of the dimension. \\
\hline $0.71-1.0$ & Very Strong \\
$0.61-0.70$ & Strong \\
$0.41-0.60$ & Moderate \\
$0.20-0.39$ & Weak \\
$0-19$ & Very Weak \\
\hline
\end{tabular}

Table 4. Correlation of retail service quality dimensions

\begin{tabular}{llccccc}
\hline Dimension & \multicolumn{1}{c}{ Relationship } & $\begin{array}{c}\text { Physical } \\
\text { Aspect }\end{array}$ & Reliability & $\begin{array}{c}\text { Personal } \\
\text { Interaction }\end{array}$ & $\begin{array}{c}\text { Problem } \\
\text { Solving }\end{array}$ & Policy \\
\hline Physical & Pearson Correlation & $\mathbf{1}$ & & & & \\
Aspect & Sig.(2-tailed) & & & & & \\
Reliability & Pearson Correlation & $\mathbf{0 . 1 3 6}$ & $\mathbf{1}$ & & & \\
& Sig.(2-tailed) & $\mathbf{0 . 0 5 5}$ & & & & \\
Personal & Pearson Correlation & $\mathbf{0 . 3 9 5}(* *)$ & $\mathbf{0 . 7 0 6 ( * * )}$ & $\mathbf{1}$ & & \\
Interaction & Sig.(2-tailed) & $\mathbf{0 . 0 0 0}$ & $\mathbf{0 . 0 0 0}$ & & \\
Problem & Pearson Correlation & $\mathbf{0 . 1 6 4}(*)$ & $\mathbf{0 . 7 3 9}(* *)$ & $\mathbf{0 . 7 3 6}(* *)$ & $\mathbf{1}$ & \\
Solving & Sig.(2-tailed) & $\mathbf{0 . 0 2 1}$ & $\mathbf{0 . 0 0 0}$ & $\mathbf{0 . 0 0 0}$ & & \\
Policy & Pearson Correlation & $\mathbf{- 0 . 0 6 8}$ & $\mathbf{0 . 5 6 4}(* *)$ & $\mathbf{0 . 4 6 7}(* *)$ & $\mathbf{0 . 5 2 8}(* *)$ & $\mathbf{1}$ \\
& Sig.(2-tailed) & $\mathbf{0 . 3 4 2}$ & $\mathbf{0 . 0 0 0}$ & $\mathbf{0 . 0 0 0}$ & $\mathbf{0 . 0 0 0}$ & \\
\hline
\end{tabular}

** Correlation is significant at the 0.01 level.

* Correlation is significant at the 0.05 level.

Physical aspect has a total Pearson correlation of $0.136,0.395,0.164$ and -0.068 with reliability, personal interaction and problem solving and policy. Three of the dimensions were significant with physical aspect as it below the significant level of 0.05 but only policy has exceeded the significant level. Therefore, physical aspect has an averagely weak relationship with reliability, personal interaction and problem solving meanwhile it has a reverse relationship with policy. A reverse relationship occur when the retailer, in this case the manager of Supermarket $X$ are highly emphasizing on policy which make them less concern on physical aspect and if they emphasizing on physical aspect their focus on policy will be reduce.

Next, reliability has a significant relationship with the other four dimensions as all of the significant value is below 0.05 . On the other hand, the Pearson correlation for reliability and the four dimensions are $0.706,0.739$, 0.564 and 0.136 .Based on the Guttmann's Rules of Thumb, reliability has a strong relationship with personal interaction and problem solving. Then, it has a moderate relationship with policy and a very weak relationship with physical aspect.

The relationships for personal interaction are as follows, it has a strong relationship with reliability and problem solving .Then, a moderate relationship with policy while a weak relation-ship with physical aspect. This statement is support by the value of Pearson correlation for relia-bility and the four dimensions which are 0.706 , $0.736,0.467$ and 0.395 . The total of the signifi-cant value for the four dimensions are also below 0.05 .

Furthermore, the fourth dimension is problem solving and it has a total Pearson correlation of $0.739,0.736$, 0.528 and 0.164 with the four dimensions. Based on the Guttmann's Rules of Thumb problem solving has a strong relationship with reliability and personal interaction, a moderate relationship with policy and a very weak 
relationship with physical aspect. All of the four dimensions are significant to problem solving.

The fifth dimension is policy and three of the dimensions have a significant relationship with policy except physical aspect comes out with a reverse relationship. Therefore, policies have a moderate relationship with personal interaction, problem solving and also reliability with the value of $0.467,0.528$ and 0.564 .The reverse relationship with physical aspect is at -0.068 .

\subsection{Regression Analysis/Hypotesis Testing}

The regression analysis is used to explore the relationship of one dependent variable and a number of independent variables. According to Pallant (2001), multiple regression is able to provide the information about the model as a whole (all subscales), and the relative contribution of each of the variables that make up the model (individual subscales).

Table 5. R square and ANOVAs for retail service quality

\begin{tabular}{ccc}
\hline Dependent Variables & R Square & ANOVAs \\
\hline Retail Service Quality & 0.939 & 0.000 \\
\hline
\end{tabular}

The R square indicates that $93.9 \%$ the Independent variables explain the Dependent variables in this research. The remaining $6.1 \%$ were explain by others factor such as Price, Promotion, Size, Consumer Behavior and so forth. ANOVAs' for Retail Service Quality were 0.000 which means the whole model is very signifi-cant as it below $\mathrm{p}>0.05$.

Table 6. Results for five dimensions of retail service quality

\begin{tabular}{llcc}
\hline Dimensions & Beta & Sig. \\
\hline 1. & Physical Aspect & 0.053 & 0.010 \\
2. & Reliability & -0.002 & 0.934 \\
3. & Personal Interaction & 0.644 & 0.000 \\
4. & Problem Solving & 0.355 & 0.000 \\
5. & Policy & 0.029 & 0.195 \\
\hline
\end{tabular}

Sig. or significance level at $\mathrm{p}>0.005$

The dimensions that below $\mathrm{p}>0.005$ were Physical Aspect, Personal Interaction and Problem Solving, meanwhile two of the dimensions were not significance to Retail Service Quality and there are Reliability and Policy. As for Reliability, it has an inverse relationship with Retail Service Quality Dimension because the more the store manager of Supermarket X emphasize on Retail Service Quality the Reliability will be less concerned .Therefore, Supermarket X must be balanced and take a depth looks into their Reliability Dimension which consist of the availability of merchandise, insisting on error-free sales transactions and records and make sure they perform their services at the time promise.

Finally, the Beta values that used to evaluate which of the dimensions were very important for Supermarket $\mathrm{X}$ in order to improve their services. The most important dimension is Personal Interaction, followed by Problem Solving, Physical Aspect, Policy and Reliability. This result were supported by Abu (2004) agrees with the importance of personal interaction between retailers and customers which will develops customer loyalty. Customers are more loyal to a store which offers warm and friendly service. In addition, the ability to truthfully answer customers' questions, giving regular customers individual attention and knowledge of their product attracts customers to shop from a particular retail outlet (Dabholkar et al. 1996; Darian et al. 2001). 


\subsection{Independent Sample T-Test}

Table 7. Gender and personal interaction

\begin{tabular}{ccccc}
\hline \multirow{2}{*}{ Variable } & Levene's Test for Equality of Variances & \multicolumn{3}{c}{ T-Test For Equality of Means } \\
& Sig. & df & Siq.(2 tailed) & Mean Difference \\
\hline Personal Interaction & 0.004 & 198 & 0.000 & -2.409 \\
\hline
\end{tabular}

Significance level at $p>0.05$

This test was to support the result for regressions analysis .The result indicates that Personal Interaction was the most importance dimension for Supermarket X, therefore by conducting Independent T-Test by using Gender as the numerical variables and Personal Interaction as the independent variables. The aim of this test is to see the difference of the response between the two groups of variables.

By focusing on the result of Levene's test, it is 0.004 and it is significant .If it is significant, the respond between the two groups are not homogeneous. These explain that both of the gender has their own reasons in evaluating the Personal Interaction dimension. Meanwhile, if the Levene's test is not significant, the responses are homogeneous and the Personal Interaction is not one of their main concerns. Moreover, the means difference in the t-test for equality of means will be used to determine which group is dominance, if the result is positive it will be the first group that is male. If the result is negative, the second group is dominance .In this study, it is dominance by Female. To make it clear, it will be measures through the highest mean values that are represented by Female by 5.92 than Male 3.51 .

Table 8. Descriptive frequency for gender

\begin{tabular}{lcc}
\hline Gender & Mean & $\mathbf{N = 2 0 0}$ \\
\hline 1. Male & 3.51 & 70 \\
2. Female & 5.92 & 130 \\
\hline
\end{tabular}

\subsection{One -Way Analysis of Variance (ANOVA)}

Independent T-test was applied to support the regression analysis by testing the numerical variables with the independent variables and comparing the mean difference to know the responses.

One Way ANOVA is used to clarify the regression analysis by comparing the means for categorical variables which involving more than two groups of variables with the independent variable to avoid the violated responses.

Table 9. Age and personal interaction

\begin{tabular}{lcc}
\hline Age (Years) & $\mathbf{N}=\mathbf{2 0 0}$ & Mean \\
\hline 19 and Below & 25 & 3.35 \\
$20-30$ & 107 & 4.99 \\
$31-40$ & 30 & 5.79 \\
$41-50$ & 33 & 5.91 \\
51 and Above & 5 & 5.93 \\
\hline
\end{tabular}

As for this method, the highest mean was the respondent among the age of 51 and above, followed by the age of 41 to 50 years, then the age between 31 to 40 years, after that the age of 20 to 30 years and for 19 and below it was the lowest mean compared to the others.

Furthermore, to support the result ANOVA analysis was conducted to clarify the relationship between the personal interaction and age of the respondents. From the significant value that obtained, it is at the significant 
level of $\mathrm{p}>0.05$.

Thus, to conclude this findings the significant value tells that all of the respondent with different range of age have their own responses towards personal interaction that offered by Supermarket $X$. If the significant value is above $\mathrm{p}>0.05$, the respondent would have zero concerned on the personal interaction of Supermarket X.

Table 10. ANOVA

\begin{tabular}{ccc}
\hline Personal Interaction & $\mathrm{df}$ & Sig. \\
\hline Between Groups & 4 & 0.000 \\
\hline
\end{tabular}

\section{Conclusions}

This research found that this supermarket has a big potential to be extended. First of all, Supermarket X received more female customer than male customer and this is a sign that Supermarket $\mathrm{X}$ is offering more female products and foods than male. Next, 68 percent of the customers are single than married customers which Supermarket $\mathrm{X}$ is favorable in servicing the single customers due to the products and foods they offered is based on instant and less fresh food that normally offered by wet market .Therefore, married customers in this study is still loyal to the wet market where they can buy all of the fresh foods in one place. Meanwhile, there are a few other races comes to Supermarket $\mathrm{X}$ to do their shopping by a total Chinese(1.5percent), Melanau (2.5 percent), other races (5 percent), Bidayuh (14 percent) .This supermarket is only known and contributes by Malay and Iban consumers. The other races should be given attention by Supermarket $X$ through a competitive price and a range of product that suits their taste.

Furthermore, the profits and sales for Supermarket $\mathrm{X}$ is only supported by the consumer age in the range of 20 to 30 years and below but the consumer in the range of age 31 to 51 above is not showing a good interest toward Supermarket X. In the other hand, in this supermarket there were highly student involvement and that is why the employees of this supermarket must maintain their personal interaction with their customer of every different range of age. Hence, to give a positive impact on their services the supermarket must create something that value for money which can attract the consumers attention to do a frequent shopping such as offering product that the other competitors does not have such as foreign products, a frozen foods that can be mixed with affordable price to consume, attractive promotion not only by reducing the actual price but offering other product to be a mysterious gift, and others.

In addition, the income of the consumers who do their shopping in Supermarket $\mathrm{X}$ can be concluded as the lower income as it dominated by below RM1000 per month. The higher and middle income customers have a less commitment toward the supermarket because the higher the education level of the consumer, it will make the consumer more demanded and they are easy to switch to the other outlets due to the better choices with better services.

Moreover, to answer the research questions which asked "what is the most important component in the retail service quality dimensions for Supermarket X?" are Personal Interaction. The above statement are supported by the result of this study which shown that Personal Interaction is the most important dimension in attracting and make the consumers to patronage in Supermarket $X$ as according to the research done by Abu (2004) which personal interaction can develops customer loyalty and as for Winsted (1997), what customers perceive as good service can be having knowledgeable, helpful and courteous salespeople Small things like smiling, greeting and establishing eyes contact may also give the customers a positive feeling about the store. The following dimensions to be emphasizing is Problem Solving through a study done by Trappey and Lai (1997), younger consumers who are more occupied with work and family prefer to shop in modern retail outlets which better satisfy the needs of a faster-paced lifestyle. Shoppers who purchase from modern retail outlets do not always live near the supermarkets. Convenience for them meant one-stop shopping. Besides that, the third dimension is Physical Aspect to be one of the important dimension based on Seiders and Tigert (2000), the consumers will only choose to shop at the store if they perceive the store has the same image desired by them. However, store image or attributes cannot be determined unless the store dimension is important to the consumers and there is a noticeable difference across the chain.

Meanwhile, to support the finding is to take into account the Policy dimension and it is supported by Kaufman (1996), an excellent service with convenience was seen from the shoppers' perspective as selecting their preferred shopping outlet based on hours of operation and travel time. The final dimension to be focus on is the 
reliability dimension as according to Morganosky (1997), Seiders and Tigert (2000) and Carpenter (2008), found that consumer preferences are affected by the perception of variety within a selection and the store itself. That is the reason why customers go to Supermarket $\mathrm{X}$ because of the employees who are willing to help customer and so friendly.

\section{Recommendations}

Through the evaluation of the dimensions of Retail Service Quality of Supermarket X, there is a lot of improvement that they should focus on the employees of Supermarket X which should be more helpful in serving their customers because this will affect the long term relationship with the supermarket. Through a good relationship with the customer, the customer will slowly put some trust and this will encourage them to be a loyal customer instead of focusing on the new customer that easily switching to the other outlets. In this matter, when employees viewed their jobs as interesting, challenging and gratifying, providing opportunities for autonomy, self-direction and the use of multiple skills and abilities, they are likely to experience a positive emotional state, which in turn, lead them to feel committed to their jobs and organization and enhance the quality (Faisal et. al, 2012)

Moreover, it is important for Supermarket $\mathrm{X}$ to organize an attractive sales promotion because it was found that promotion will help to build patronage and store traffic (Carpenter and Moore, 2008; Ruiz and Decals', 2008), temporarily increase sales of the promoted brands (Blatterb et al, 1995), and affect sales of other items (Kumar and Leonne, 1988; Sivakumar, 2003; Ruiz and Descales, 2008).

Finally, Supermarket X must have some creativity in order to be the first choice of consumers which the consumers are mostly attracted to point-of-purchase variables includes point-of-purchase displays, signs, product display, and price display (Turley and Milliman, 2000). According to Chevalier (1975), a significant percentage of total sales in a supermarket come from point of purchase displays. This is because customers tend to believe these are special bargains and often buy something from the display even if they had no intention of buying the item before they visited the store.

\section{References}

Ahmad et al. (1996). Basic Retailing. Shah Alam: Institut Teknologi MARA.

Carpenter, J. M. (2008). Demographics and Patronage Motives of Supercenter Shopper in the United States. International Journal of Retail \& Distribution Management, 31(1), 5-16. http://dx.doi.org/10.1108/09590550810846965

Cox, R. (1988). Retail Management. London: Longman Group.

Dabholkar, P. A., Thorpe, D. I., \& Rentz, J. O. (1996). A measure of service quality for retail stores: scale development and validation. Journal of the Academy of Marketing Science, 24(1), 3-16. http://dx.doi.org/10.1007/BF02893933

Finn, D. W., \& Lamb, C. W. (1991). An evaluation of the SERVQUAL scale in a retailing setting. In R. Holman, \& M. R. Solomon (Eds.), Advances in Consumer Research, Association for Consumer Research (pp. 483-490). Provo, UT.

Gagliano, K. B., \& Hathcote, J. (1994). Customer expectations and perceptions of service quality in retail apparel specialty stores. Journal of Services Marketing, 8(1), 60-69. http://dx.doi.org/10.1108/08876049410053311

Government of Malaysia. (1996). Seventh Malaysia Plan 1996-2000. Kuala Lumpur: Percetakan Nasional Malaysia Berhad.

Guy, M. C. (1980). Retail Location and Retail Planning in Britain. University of Wales: Institute of Science and Technology.

Hurley, R. F., \& Estelami, H. (1998). Alternative indexes for monitoring customer perceptions of service quality: a comparative evaluation in a retail context. Journal of the Academy of Marketing Science, 26(3), 209-221. http://dx.doi.org/10.1177/0092070398263003

Mahdi, A. F., Zin, M. Z. M., Nor, M. R. M., Sakat, A. A., \& Naim, A. S. A. (2012). The Relationship between Job Satisfaction And Turnover Intention. American Journal of Asian Sciences, 9(9), 1518-1526.

Mehta, S. C., Lalwani, A. K., \& Han, S. L. (2000). Service quality in retailing: relative efficiency of alternative measurement scales for different product-service environments. International Journal of Retail \& Distribution Management, 28(2), 62-72. http://dx.doi.org/10.1108/09590550010315106 
Mui, L. Y., Badarulzaman, N., \& Ahmad, A. G. (2003). Retail activity in Malaysia: from shophouse to hypermarket. Paper presentation at the Pacific Rim Real Estate Society 9th Annual Conference, Brisbane, 20-22 January.

Nik et al. (1992). Basic Marketing. Kuala Lumpur: Fajar Bakti

Parasuraman, A., Zeithamal, V. A., \& Berry, L. L. (1988). SERVQUAL: A Multiple-Item Scale for Measuring Customer Perceptions of Service Quality. Journal of Retailing, 64(1).

Seiders, K., \& Tigert, D. J. (2000). The Impact of Supercenters on Traditional Food Retailers in Four Markets. International Journal of Retail \& Distribution Management, 28(4-5), 181-193. http://dx.doi.org/10.1108/09590550010319931 